\title{
Research on Knowledge Creation Mechanism of Government in Industry University Research Cooperation Mode
}

\author{
Hongyan Zhang ${ }^{1, *}$, Yajing Liu $^{1}$ and Haixia Zhang ${ }^{1}$ \\ ${ }^{1}$ School of Economics and Management, Harbin University of Science and Technology, Harbin, Heilongjiang 150000, \\ China \\ *Corresponding author. Email: 16111009@bjtu.edu.cn
}

\begin{abstract}
As a significant form of Inter Organizational cooperation, industry university research cooperation has always played an important role in national technological innovation and economic development. This paper divides the industry university research cooperation model into government led and non-government led, and elaborate the knowledge of creation mechanism of these two models with the help of SECI's knowledge creation model. By comparing with the different mechanisms of the two models, this paper finds the path of the government in improving the knowledge of creation performance of industry university research cooperation.
\end{abstract}

Keywords: Industry university research cooperation; knowledge creation; government; tacit knowledge; explicit knowledge

\section{INTRODUCTION}

Industry university research cooperation can greatly promote the economic performance of a country, region and even enterprises [1]. However, after nearly 30 years of development, the cooperation with efficiency is still not optimistic. In reality, the level of domestic university research cooperation is not high, which mainly shows that tens of thousands of enterprise technical needs can not be met and the achievements of scientific research institutions can not be industrialization. From the perspective of international comparison, the comprehensive level of domestic university research cooperation urgently needs to be further improved. The statistical results show that tens of thousands of scientific and technological achievements are produced by universities and scientific research institutes in China every year. Nevertheless, at present, many scientific and technological achievements can not be quickly and effectively transformed into real productivity. Especially in the typical indicators such as the proportion of $\mathrm{R} \& \mathrm{D}$ investment in colleges and universities, the proportion of cooperative patents, the proportion of academic entrepreneurship, and the intensity of industry university research cooperation of enterprises, there are different degrees of gaps compared with major developed countries. The main problems include: the separation of functions between industry, universities and research institutes, insufficient attention to industrial demand, incompatible incentives, etc., resulting in disconnection, single form of cooperation, low enterprise enthusiasm, underdeveloped intermediary system, few preferential policies and high threshold [2].

In 1992, the launch of the "industry university research joint development project" was an important symbol of the official beginning of China's domestic university research cooperation. Industry university research cooperation can greatly promote the economic performance of a country, region and even enterprises. Quite a few scholars have defined industry university research cooperation. The meaning of industry university research cooperation can be divided into broad sense and narrow sense, and knowledge can also be divided into explicit knowledge and tacit knowledge. From the perspective of knowledge creation, "industry university research cooperation" in a broad sense refers to the organic combination of technological development, talent training and production activities of colleges and universities, enterprises and scientific research institutes under the influence of government, intermediary institutions, financial and venture capital institutions, and on the principle of complementary advantages, mutual benefit and common development, the cooperative process of knowledge creation is realized through the diffusion of tacit knowledge and explicit knowledge. In a narrow sense, "industry university research cooperation" refers to the organic combination of colleges and universities, enterprises and scientific research institutes in technology development, talent training and production activities, and the realization of knowledge creation through the diffusion of tacit knowledge and explicit knowledge on the principle of complementary advantages, mutual benefit and universal development. Because this paper studies the relationship between industry university research cooperation mode and the knowledge creation, there is no 
great difference in the essence of knowledge between colleges and universities and learning research institutions. They play a very similar role in industry university research cooperation. Therefore, this paper does not make a strict distinction between colleges and universities and learning research institutions, which is collectively referred to as "learning research institutions".

\section{CLASSIFICATION OF INDUSTRY UNIVERSITY RESEARCH COOPERATION MODE}

Industry university research cooperation mode is generally divided into the technology transfer, technology development, co-construction entity, University Science and Technology Park, entrusted training and other modes. Scholars have conducted rich research on the classification of industry university research cooperation modes, including the classification of close cooperation modes and loose cooperation modes according to different degrees of combination [3]. There is the classification of one-to-one cooperation modes and one to many cooperation modes according to the different number of cooperation between universities and enterprises [4]. There are different classifications of market spontaneous model, government guidance model and government of leading model according to the different functions of the government [5]. More scholars divide industry university research into the market-oriented, university research oriented and government oriented according to the difference of leading forces. In order to analyze the government's knowledge creation of mechanism in industry university research cooperation, this paper divides the industry university research cooperation mode into government guided industry university research cooperation mode and nongovernment guided industry university research cooperation mode.

\section{KNOWLEDGE CREATION MECHANISM IN INDUSTRY UNIVERSITY RESEARCH COOPERATION UNDER THE GUIDANCE OF NON-GOVERNMENT}

Yujiro Nonaka (1995) believes that organizational knowledge creation is the process of creating new knowledge, diffusing new knowledge in the organization and integrating this new knowledge into products, services and systems. Knowledge is divided into two categories: explicit knowledge[6] and tacit knowledge[7]. Explicit knowledge is transmitted in coded forms such as language, text, graphics and symbols, usually in the form of documents, product appearance, database system, product instructions and software programs. This way can realize the separation of knowledge sending and receiving in time and space with the help of information technology and the modern network technology, It overcomes the limitations of knowledge diffusion mode on time and space, so as to improve the efficiency of knowledge diffusion. Tacit knowledge is the comprehensive embodiment of personal experience and ability. It is frequently difficult to express it in coded and formal language, such as beliefs, metaphor, intuition, thinking mode and so-called "know-how". It is embedded in personal work experience and practical activities. Brain, experience and memory are the necessary conditions for the existence of tacit knowledge. Knowledge creation is a process of interaction and transformation between tacit knowledge and explicit knowledge. Referring to figure 1 , there are four basic modes of knowledge transformation - socialization that is the first stage (transformation from tacit knowledge to tacit knowledge), externalization is the second stage (transformation from tacit knowledge to explicit knowledge), combination is the third stage (transformation from explicit knowledge to explicit knowledge), and internalization is the fourth stage (transformation from explicit knowledge to tacit knowledge), that is, the famous SECI model [8].

\begin{tabular}{l|l|l|}
\multicolumn{1}{c}{ tacit knowledge } & \multicolumn{1}{c}{ explicit knowledge } \\
tacit & $\begin{array}{l}\text { socialization } \\
\text { knowledge }\end{array}$ & $\begin{array}{c}\text { externalization } \\
(\text { first stage })\end{array}$ \\
\cline { 2 - 3 } $\begin{array}{l}\text { explicit } \\
\text { knowledge }\end{array}$ & $\begin{array}{c}\text { internalization } \\
(\text { fourth stage })\end{array}$ & $\begin{array}{c}\text { combination } \\
(\text { third stage })\end{array}$ \\
\cline { 2 - 3 } & &
\end{tabular}

Figure 1. Knowledge creation model in industry university research cooperation under the guidance of non-government

Under non-governmental guidance, the knowledge creation of mechanism in industry university research cooperation is a platform for learning and research parties and enterprises to jointly build the knowledge creation. What learning and research parties and enterprises deliver to the platform is tacit knowledge. On the platform, tacit knowledge creates explicit knowledge through the four stages proposed in SECI knowledge creation model. As shown in Figure 2.

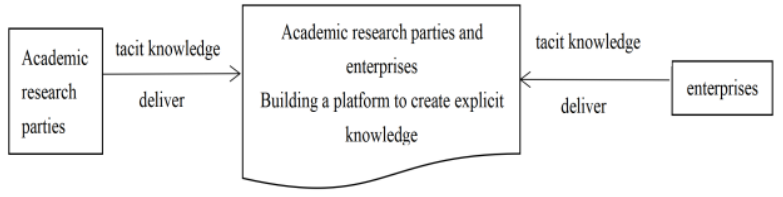

Figure 2. Knowledge creation process in industry university research cooperation under the guidance of non-government 


\section{KNOWLEDGE CREATION MECHANISM IN INDUSTRY UNIVERSITY RESEARCH COOPERATION UNDER THE GUIDANCE OF GOVERNMENT}

The industry university research cooperation under the guidance of the government has not changed in essence of the knowledge creation. It is still the direction platform for universities and enterprises to transfer tacit knowledge. The difference is that the knowledge creation of industry university research cooperation at this time is guided by the government. Liu Yulin (2005) according to the research, the decision-making behavior of relevant government departments, such as the expenditure on scientific and technological innovation activities and the construction support for regional economic environment and scientific and technological environment, is an important factor affecting industry university research cooperation[9].

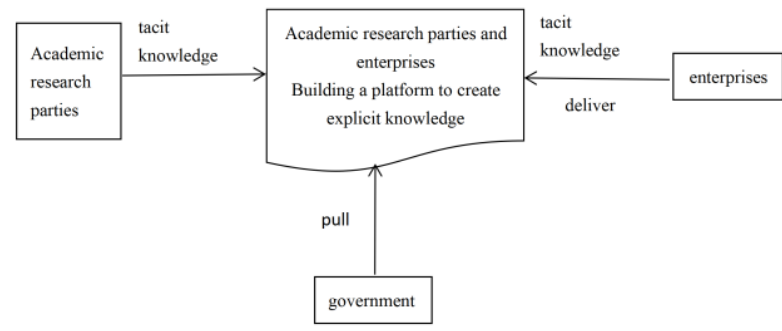

Figure 3. Knowledge creation process in industry university research cooperation under the guidance of government

In terms of knowledge of creation mechanism, in the first stage, both sides of the platform acquire tacit knowledge from each other. Generally, enterprises and academic research for parties send personnel to each other for learning. At this time, the role of the government is to encourage colleges and universities to serve society to train enterprise personnel and encourage students to practice in enterprises; in the second stage, both sides of the platform transform from tacit knowledge to explicit knowledge, which generally occurs when both sides jointly develop new patents or jointly publish articles. At this time, the role of the government is to encourage joint invention patents and jointly publish articles; in the third stage, the transformation from explicit knowledge to explicit knowledge between the two sides of the platform generally occurs when learning and research transfer technology to enterprises. At this time, the role of the government is to encourage academic research for parties to develop of new knowledge and allow the market-oriented operation of the developed new knowledge. At the same time, enterprises are encouraged to purchase academic research parties' new technologies, and tax preference should be given to the purchase of academic research parties' new technologies; In the fourth stage, the transformation from explicit knowledge to tacit knowledge of the platform generally occurs when members of enterprises and research institutes acquire new knowledge. At this time, the role of the government is to encourage members' own growth and clarify the incentive policies in members' career planning as shown in Table 1.

Table 1. Knowledge creation model in industry university research cooperation under the guidance of government

\begin{tabular}{|l|l|}
\hline $\begin{array}{l}\text { Socialization (first stage) } \\
\text { (government encourages colleges and } \\
\text { universities to serve the society to train } \\
\text { enterprise personnel and encourage } \\
\text { students to practice in enterprises) }\end{array}$ & $\begin{array}{l}\text { externalization (second } \\
\text { stage) } \\
\text { (government encourages } \\
\text { joint invention patents and } \\
\text { jointly publish articles) }\end{array}$ \\
\hline $\begin{array}{l}\text { internalization (fourth stage) } \\
\text { (government encourages members' own } \\
\text { growth and clarify the incentive policies } \\
\text { in members' career planning) }\end{array}$ & $\begin{array}{l}\text { combination (third stage) } \\
\text { (tax preference will be } \\
\text { given to enterprises to } \\
\text { purchase new technologies } \\
\text { created by researchers) }\end{array}$ \\
\hline
\end{tabular}

\section{CONCLUSIONS AND RECOMMENDATIONS}

This paper divides the industry university research cooperation mode into government guided industry university research cooperation mode and non-government guided industry university research cooperation mode. Each industry university research cooperation model follows the law of knowledge creation, that is, SECI knowledge creation model. However, with the participation of the government, the role of the government in different stages of SECI model is different. In the socialization stage, the government should encourage colleges and universities to train enterprise personnel and encourage students to practice in enterprises; in the externalization stage, the government should encourage joint invention patents or publishing articles; In the United stage, the government should encourage internal members to pursue their own growth; in the internalization stage, the government should give tax preference to purchase new technologies created by researchers. Only when the government participates in every stage of knowledge creation can industrialize university of research cooperation achieves the purpose of knowledge creation. Knowledge creation depends on the policy support and supporting supply of the government. Therefore, the longterm and stable cooperation of industry university research is inseparable from the participation and guidance of the government.

\section{DEFICIENCY AND PROSPECT}

Starting with SECI's knowledge creation model, this paper studies the role and mechanism of the government in industry university research of cooperation, and obtains the path for the government to participate in industry university research of knowledge creation. However, due 
to the limited space, there is no in-depth analysis on the degree of government participation. In the future, we can start with the degree of government participation in guiding industry university research cooperation.

\section{ACKNOWLEDGMENT}

The key project of Heilongjiang Education Science "13th five year plan" in 2020: Research on the innovative talent training mode of Heilongjiang Universities from the perspective of government industry university research cooperation Subject number: GJB1320109;

Research on the innovation of the development mode of industry university research cooperation that is in Heilongjiang Province from the perspective of knowledge diffusion. Subject Number: 2018-KYYWF-006

\section{REFERENCES}

[1] Jingbo Zhao, Economic Performance Research, Model and Mechanism Analysis of Domestic University Research Cooperation in China, Jilin University, 2012.

[2] Hongru Xiong, Investigation and Research Report, Innovation and Development Research Department of development research center of the State Council, 2020.

[3] Changhong Yu, Research on the choice of industry university research cooperative innovation mode based on enterprise technical capability, Dalian University of Technology, 2019.

[4] Liu Shi, Research on the mode of industry university research cooperation in American research universities and Its Enlightenment to China, Hunan Normal University, 2017.

[5] Wenyan Wang, Fuquan Sun, Qiang Shen, Classification, characteristics and selection of industry university research cooperation mode, China Science and Technology Forum, 2008, vol. 05, pp. 37-40.

[6] Gilbert M, Cordey-Hayes M. Understanding the process of knowledge transfer to achieve successful technological innovation[J]. Technovation, 1996, 16(6): 301-312.

[7] Maskell P. Knowledge creation and diffusion in geographic clusters[J]. International journal of innovation Management, 2001, 5(02): 213-237.

[8] Ikujiro Nonaka, Hirotaka Takeuchi . The Knowledge-Creating Company. Oxford University Press, USA. 1995.

[9] Yulin Liu, Analysis report on China's regional innovation capability from 2004 to 2005, Management of science and technology, 2005(12), PP. 5-14. 